DOI: https://doi.org/10.34069/AI/2021.45.09.21

How to Cite:

Kyrychenko, O.V., Soldatenko, O.A., Gorokhovska, O.V., Voloshyna, M.O., \& Maksymova, L.O. (2021). Fraud in the banking system of Ukraine: ways to combat taking into account foreign experience. Amazonia Investiga, 10(45), 208-220. https://doi.org/10.34069/AI/2021.45.09.21

\title{
Fraud in the banking system of Ukraine: ways to combat taking into account foreign experience
}

\section{ШАХРАЙСТВО В БАНКІВСЬКІЙ СИСТЕМІ УКРАЇНИ: СПОСОБИ БОРОТЬБИ ІЗ ВРАХУВАННЯМ ЗАРУБІЖНОГО ДОСВІДУ}

Received: July 12, 2021

Accepted: September 9, 2021

\begin{abstract}
The article aims to identify effective ways to combat bank fraud in Ukraine. Using the method of systematic analysis of theoretical experience, practical measures and international legislation in the field of combating banking fraud, the main factors influencing the bank fraud level are identified: financial instability of the banking institution, lack of information about the client's credit history, poor internal control, low level of corporate governance, lack of a standard procedure for customers verification, lack of a unified register of bank employees, imperfect legal regulators and a banking control system. The study allowed to identify the characteristics of an effective banking fraud combating system: a clear definition of the legal framework, regulation subjects and objects, strict and guaranteed liability for violations of laws, cooperation of structural units and regulatory authorities at the domestic and international level, state control of financial monitoring. As a result of the study, it was concluded that the successful experience of developed countries,
\end{abstract}

\begin{abstract}
Анотація
Статистичні дані про рівень банківського шахрайства в розвинених та країнах, що розвиваються, свідчать про доцільність створення ефективної системи боротьби 3 цими видами злочинів. Стаття покликана визначити ефективні шляхи боротьби 3 банківськими шахрайствами в Україні. За допомогою методу системного аналізу теоретичного досвіду, практичних заходів та міжнародного законодавства у сфері протидії банківським шахрайствам визначено основні фактори, що впливають на рівень банківського шахрайства. Такими факторами $€$ : фінансова нестабільність банківської установи, відсутність інформації про кредитну історію клієнта, поганий внутрішній контроль, низький рівень корпоративного управління, відсутність стандартної процедури перевірки клієнтів, відсутність єдиного реєстру працівників банку, недосконалі правові регулятори та система банківського контролю. Дослідження дозволило виявити характеристики
\end{abstract}

\footnotetext{
${ }^{81}$ Doctor of Law Sciences, Associate Professor, Rector Private institution of higher education "Dnipro humanitarian university", Dnipro city, Ukraine.

${ }^{82}$ Candidate of Juridical Sciences, Associate Professor, Dnipropetrovsk State University of Internal Affairs, Dnipro city, Ukraine.

${ }^{83}$ Associate Professor, PhD in Law, Head of the Department of Theory, History of State and Law and International Law, Classical Private University, Zaporizhzhia city, Ukraine.

${ }^{84}$ Ph.D, Associate Professor of the Department of Operative - Investigative Activity Dnipropetrovsk State University of Internal Affairs, Dnipro city, Ukraine.

${ }^{85}$ Candidat of legal sciences, Associate Professor, Kyiv University of Tourism, Economics and Law, Kyiv, Ukraine.
} 


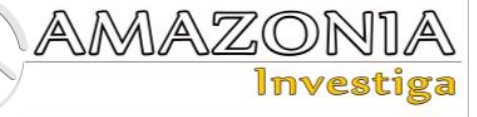

comprehensive implementation of measures to combat bank fraud (at the legislative, bank management and technological level) will not only reduce the level of bank fraud, but also corruption, money laundering and terrorist financing rate.

Key words: financial institution, crime, control, security, information, legal regulation, Ukraine.

\section{Introduction}

Inter-temporal changes in modern reality and current trends in society increase the need to obtain only the most necessary information in a few seconds, without being overloaded with related information; the main principle is access to information with just "one click". Such information development, publicity and simplification of access to information gives new opportunities for the society development. The other side of this process is offering new opportunities for financial crimes and fraud in all spheres of life. Banking system is one of the most vulnerable areas for fraud. Despite audits by financial institutions and financial transactions control, verification of customer bases and continuous improvement of the security system, fraud related to financial transactions is becoming more common.

The rapid pace of banking sector modernization, the emergence of new payment systems and methods of mutual settlements has become the basis for the emergence of various forms of fraud requiring legal regulation and identification of possible ways to combat such crimes. The common forms of fraud involve the use of digital signatures, online transactions, plastic cards. This situation becomes the basis for changing the form of fraud, its globalization and internationalization.

ефективної системи боротьби з банківськими шахрайствами: чітке визначення законодавчої бази, суб'єктів та об'єктів регулювання, сувору та гарантовану відповідальність за порушення законів, співпрацю структурних підрозділів та контролюючих органів на внутрішньому та міжнародному рівнях, державний контроль фінансового моніторингу. В результаті дослідження було зроблено висновок, що успішний досвід розвинутих країн, всебічне впровадження заходів щодо боротьби 3 банківськими шахрайствами (на законодавчому рівні, на рівні управління банками та на технологічному рівні) не тільки знизять рівень банківського шахрайства, але також корупції, відмивання грошей та фінансування тероризму, що сприятиме зростанню довіри населення до банків та фінансової стабільності.

Ключові слова: фінансова установа, злочинність, контроль, безпека, інформація, правове регулювання, Україна.

In 2019 the KPMG international company undertook a global study in 43 retail banks in regard to the commitment and combating bank fraud. The study found that more than half of respondents worldwide experienced an increase in the total cost and volume of external fraud, in $201861 \%$ of respondents reported of an increase in the total number of external fraud cases, and $59 \%$ of respondents reported of an increase of fraudulent transaction amounts. Banks around the world experience a tendency of fraud level increase. Fraudsters manipulate and force customers to make payments to them, bypassing banking control (KPMG, 2019). Fraudsters are becoming more sophisticated and can change and adapt their approaches very quickly. Banks need to be shifty to be able to respond to new threats and apply new approaches and technologies to predict and prevent fraud.

The share of products and services sold by banks through digital channels is growing. According to the World Payments Report (BNP Paribas, 2018), the share of non-cash transactions will increase by a total of $12.7 \%$ by 2021 . According to a global study of economic crime and fraud conducted by PwC (2020), relatively low percentages of financial institutions investigate fraud cases and regularly monitor financial performance. $26 \%$ of Ukrainian companies have suffered losses caused by fraud ranging from $\$ 50,000$ to $\$ 1$ million during the last two years, 
and $3 \%$ of Ukrainian respondents have reported fraud losses of more than $\$ 5$ million $(\mathrm{PwC}$, 2020).

Statistics of developed countries concerning fraud rate show that this issue is topical for many countries. $81 \%$ of US organizations were attacked by payment fraud in 2019 , which is the second highest percentage since 2009. However, only $60 \%$ of them have implemented anti-fraud policies. The level of missing card fraud (CNP) continues to grow from year to year in Europe. Within the Single Euro Payments Area (SEPA) in 2018, CNP fraud amounted to $€ 1.43$ billion of fraud losses, which is $17.7 \%$ more compared to 2017. In contrast, ATM fraud decreased by $14.7 \%$ from 2017 to 2018 , which is largely due to the increasing use of chip-and-pin transactions cards in ATMs (Merchant Savvy, 2020).

This situation can adversely affect not only the profitability of banking institutions, but also macroeconomic variables (Bhasin, 2016). The growing level of financial fraud, the consequences it leads to and the low effectiveness of combating against such crimes indicates the expediency of determining an effective system for detecting and combating financial fraud in the banking sector

The article aims to identify effective ways to combat banking fraud in Ukraine on the basis of a systematic analysis of theoretical experience and practical measures to combat fraud in the banking system.

\section{Methodology}

Banking fraud is the subject of interdisciplinary research. The object of study refers to research areas of law, economics and psychology.

Therefore, a comprehensive analysis of banking fraud, which includes general theoretical and special methods of cognition, is appropriate. The methodological basis of the study includes such general scientific methods as the dialectical method of scientific knowledge, which determines the development of banking fraud, as well as the relationship between banking fraud and other crimes (corruption, cybercrime, money laundering). Using the classification method, the main types and forms of bank fraud are identified. System analysis allowed to determine the causes of fraud in the banking sector. The grouping method and the system-structural approach allowed to classify modern frauds in the banking sector. The logical-legal method allowed to determine the main measures to combat banking fraud in Ukraine. The method of comparative law, which is used to compare the legislation of countries with low levels of banking fraud, has identified effective measures to combat and reduce fraud in the banking system. Due to the method of generalization, conclusions and proposals for research are formulated.

\section{Literature review}

As reported in ACFE (2014), banking institutions are becoming more susceptible to fraud, although various control measures have been implemented. A global survey concerning bank fraud was conducted by KPMG company (2013) reports that $85 \%$ of respondents believe that fraud is increasingly occurring in the industries inclined to fraud risk. The banking industry is mainly an industry of risk, and one of the industries that is classified as an area of high fraud risk (Kingsley, 2012). The propensity of the banking sector to fraud risk also affects the level of money laundering. "Increasing the level of money laundering is influenced by incomplete identification of users when using Internet banking and online transactions; evasion of financial institutions from conducting audits for fear of losing their customers' trust" (Vitvitskiy et al, 2021a).

V.V. Pivovarov (2013) notes that latent crime in the banking sector is a vivid and visible manifestation of corporate crime committed in the banking sector. "The most common crimes in the banking sector is fraud using payment cards and their details, unauthorized debiting of bank accounts, interference with Internet banking, the spread of computer viruses, DDoS-attacks on Internet resources, fraud in information networks." (Vitvitskiy et al, 2021b).

Among the scientific approaches to understanding the concept of "financial fraud" the similar approaches can be distinguished, which, in turn, can be divided into two groups: scientific-theoretical approach and practical functional approach (Rodchenko \& Zhivko, 2020).

According to the scientific-theoretical approach, financial fraud is understood as a set of interconnected and common in terms of forensic technology selfish encroachments on the financial resources of the state, business entities and citizens, committed by deception and abuse of office (Cherniavskyi, 2010). Financial fraud is a criminological phenomenon that constitutes a criminal activity and is expressed in a system of criminal and legal actions committed by 


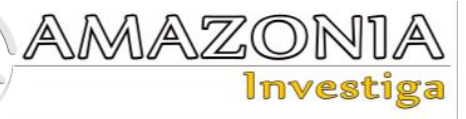

deception or abuse of trust in the process of formation, distribution and use of funds for material gain (Chernyshov, 2014).

Wells (2008) puts emphasis on the use of one's probably official position for personal enrichment. Fraud is one of the most serious, expensive, stigmatizing and punitive forms of liability imposed on today's corporations and financial markets (Buell, 2011; Green, 2007).

According to Agwu (2013), fraud is considered as any illegal act characterized by deception, concealment or breach of trust. These actions do not depend on the threat of violence or physical force. Entities and organizations commit fraud to obtain money, property or services; to avoid payment or loss of services; or to provide personal or business advantage. Research on fraud detection and prevention has been highlighted in audit procedures and appeal to "Red Flags". As explained by Gullkvist \& Jokipii (2013), "Red Flags" is a warning sign or symptom that indicates the likelihood of fraud for professionals in the field of financial criminology.

In terms of financial market activities - banking, securities and insurance - fraud is given more specific meaning and is best understood as illegal falsification or manipulation of financial information (Neil \& Roehrkasse, 2013). Financial information is considered as a support for financial market operations (Lomnicka, 2008).

There are two types of fraud in criminal proceeding related to banking activities; in particular external and internal fraud (Sanusia et al, 2015). Fraudsters are divided into three main groups: "household" (individuals) fraudsters, professional fraudsters and borrowers who use the services of professional fraudsters (Kuznetsova, 2016a; Siddiqi, 2006). It is also important to identify friendly fraud, also known as "civil fraud" or "family fraud." This applies to fraud committed using information, which belongs to an intimate friend or a family member (Bhasin, 2007).

The strongest protection against this type of fraud is to emphasize to clients the importance of maintaining the complete confidentiality of their passwords (Haugen and Selin, 1999; Agwu, 2012).

The ways of committing fraud in the banking sector are classified by L.I. Kriushenko (2015). The ways to commit fraud in the banking sector are distinguished as follows, depending on: intent; typical traces; the stage of entering knowingly false information; type of credit and banking transaction; the nature of the mechanism for obtaining a credit and banking transaction; the nature of the employment relationship of the entity with the banking institution; existence of certain agreements; the method of entering knowingly false information in the documents; the actions for preparation and concealment.

O.V. Krishevich (2012) classifies bank fraud in criminal proceedings according to three grounds:

1) the type of banking operations by means of which the crime is committed;

2) the nature of the relationship of the subject of the crime with the bank:

3) separate mechanisms of criminal activity.

A. Mordvinkin (2014) offers several classifications relating to financial fraud in a commercial bank:

- classification of the type of events which have led to losses;

- classification of bank fraud;

- classification of credit fraud types of legal entities.

The key contributing factor facilitating fraud is poor internal control (KMPG, 2019) and poor corporate governance practices (Beasley, 1996; ACFE, 2014). As banking institutions carry out a wide range of activities, fraud can potentially be committed by various parties, including shareholders, depositors, borrowers, staff, and the bank itself.

The main causes of fraud in the banking sector are: the lack of standard customer verification procedures and the unavailability of reliable information about the customer's credit history; lack of a unified register of employees of credit and financial institutions, imperfection of public relations legal regulators; inefficiency of the bank activities control system, low level of material security of the population and unemployment (Klochko, 2015).

Fraud is committed for the following reasons: perceived pressure, anticipated opportunity and rationalization. These three elements or basic concepts were taken from the "Fraudulent Triangle Theory" founded by Donald R. Cressey (Omar et al., 2010).

Analyzing the threats to banking security, O.I. Baranovskyi (2014) has noted that the 
significance of classifying financial security threats lies in the need to assess soberly the current situation, assess the negative aspects and trends of their development, group negative and positive actions of factors and on this basis to develop sound recommendations for making specific decisions to ensure the appropriate security level.

Ukraine is one of the leading countries in the world regarding bank fraud and is among the top five countries where bank payment transactions are unsecured. 19\% of transactions suspected of fraud turned out to be really fraudulent. This index exceeds the fraud extent in other countries. Thus, in 2017 with the help of cyber fraud, 8900 dollars were withdrawn from the cards of Ukrainian citizens (Fraud Digest, 2017).

The largest share of fraudulent bank transactions carried out applying social engineering methods $(41 \%)$ was implemented using fitting and pretexting. The essence of such fraudulent actions is to defraud payment card data from customers and gain access to accounts and stolen funds. The victims of social engineering are usually people of retirement age (aged 55 and older) - $15 \%$ and middle-aged people (aged 3544) - $13 \%$. The popular method of money stealing from bank customers is through ATMs $(32 \%)$ and via the Internet $(16 \%)$. Taking into consideration the popularity of these types of bank fraud, banks need to develop ways to protect their transactions. In fairness, it should be noted that bank fraud implemented using social engineering is not only a problem of Ukraine, but a global problem (Rodchenko \& Zhivko, 2020).

Often the victims of ATM fraud (in particular, by "trapping" and "phantom" method) are people who do not live permanently in the relevant area, namely tourists. Insufficient awareness, combined with the stressful situation created by a fraudster, contributes to the victimization of such persons and attracts the increased attention of criminals (Afanasenko, 2014).

In the field of bank card fraud, the victim's behavior plays a decisive role. According to scientists, the main reasons for the crime commitment are the inattention of the victim, lack of sufficient critical thinking, his or her own carelessness and propensity to risk-taking. K.L. Popov (2015) notes that risk often becomes the last argument for a person in favor of participation in situations of doubtfulness or uncertainty, which involve obtaining significant benefits, achieving significant advantages, but at the same time are potentially dangerous given the possibility of unpleasant consequences.

The difficulty of legal regulation of bank fraud in criminal proceedings is that fraud must involve both dishonesty and intent to either gain benefit or cause damage (which must be a profit or loss in terms of money or other property). Such traits are subjective classifications and therefore they are difficult to be justified objectively (Sharma, 2004; Agwu, 2013). Fraudsters are becoming more sophisticated, which means that fraud precautions should be constantly evolving to ensure that they are able to counter the threat (Agwu, 2014).

For example, most types of fraud in the UK fall under one of the laws. The Law on Fraud establishes certain types of fraud that cannot easily fit into the categories of this law. These include possession of documents (including electronic data and programs) for fraudulent use, drafting such documents to obtain services dishonestly (Okpara, 2009).

French statistics on the level of bank fraud show the effectiveness of the system for combating these types of crimes. According to the French Observatory for Payment Security (OSMP), the figures for 2017 show that losses decreased by $9.8 \%$ (467.0 million euros) compared to 2016. In the UK, there is an increase in banking fraud. In 2016, bank card fraud in the UK caused losses of $8.8 \%$ more than in 2015. However, in 2017 there was a decline of $8.4 \%$ since 2016. In May 2019, the UK developed a new payment security system in which the CoP is an important tool to prevent payment fraud (Nets Fraud \& Dispute services, 2019).

Rodchenko \& Zhivko (2020) states that banking payment systems that have poor protection may lose customers because they may be subject to fraud. Involving large sections of the population in non-cash transactions and the possibility of sustaining losses among them turns bank fraud not only into a problem of banks, but into a social problem. This problem needs to be solved comprehensively with the involvement of the state, population, banks, and investors.

\section{Results and discussion}

The main ways to commit banking crimes can be divided into 4 main groups:

1. Information interception: direct interception and electromagnetic interception. 


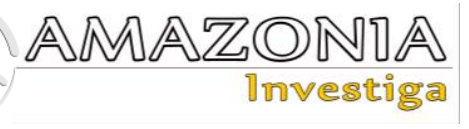

2. Unauthorized access to information: "computer boarding", "hoax", "disguise", "inconstant choice", "by the tail", "emergency", "by a fool", "break", "hatch", " warehouse without walls", "system lookyloos".

3. Manipulation of information: "Trojan horse in chains", "Trojan nest-doll", data substitution, code substitution, computer viruses, "salami", "logic bomb", "asynchronous attack", simulation, "kite", "bait trap".

4. Obtaining and using information for criminal purposes: software theft, theft of equipment through computer operations, money theft by obtaining secret codes, money theft by computer transfer, money theft by means of computer manipulation, introducing changes in the program (Dzhuzha, Golosnichenko, \& Chernyavsky, 2000).

The use of special information technologies that would detect fraudulent plans of attackers at the stage of loan applications consideration is currently topical for the banking sector. In this respect, the important task of risk management is to distinguish between fraud credit risks and defaults (impossibility of further fulfillment of their credit obligations) (Buchko, 2013).

In world practice, different types of scoring are used at different stages of crediting, but not only at the stage of loan application consideration, continuing to assess the significance of the loan application throughout the life of the loan, as well as at the stage of debt collection and transfer to collectors. At any stage of credit history with the help of scoring, it is possible to solve various tasks, such as:

1. Scoring according to current data during the application process - assessment of the potential borrowers' credit capacity based on the information provided during the credit transaction.

2. Scoring during the credit period, when assessing the dynamics of the borrower's credit account allows you to mathematically estimate the probability of the credit reimbursement.

3. Assessing the probability of full or partial reimbursement of the credit offers to determine the priority areas of work regarding borrowers, when their credit account is classified as "unsatisfactory".

4. Assessment of fraud possibility determines the likelihood of potential wrongful acts of the borrower (Narain, 1992).

The main way to combat fraud is to update constantly scoring models to detect fraud, change their parameters, increase the speed of operations monitoring, increase IT tools and maintain strong collaborative relationship with cyber police. It is offered to use scoring models and special scoring technologies to detect fraudulent actions at the stage of a loan application consideration or at attempt to obtain unauthorized money from bankcards. (Kuznetsova, 2016b).

The main reasons of bank fraud are:

- imperfection of financial institutions internal control;

- low level of banks corporate governance practices;

- lack of standardized customer verification systems;

- information unavailability about the previous credit history of clients;

- lack of a unified register of banking institutions employees;

- imperfection of legal regulators of public relations in the banking system of Ukraine;

- low efficiency of the control system over the activities of banks. 

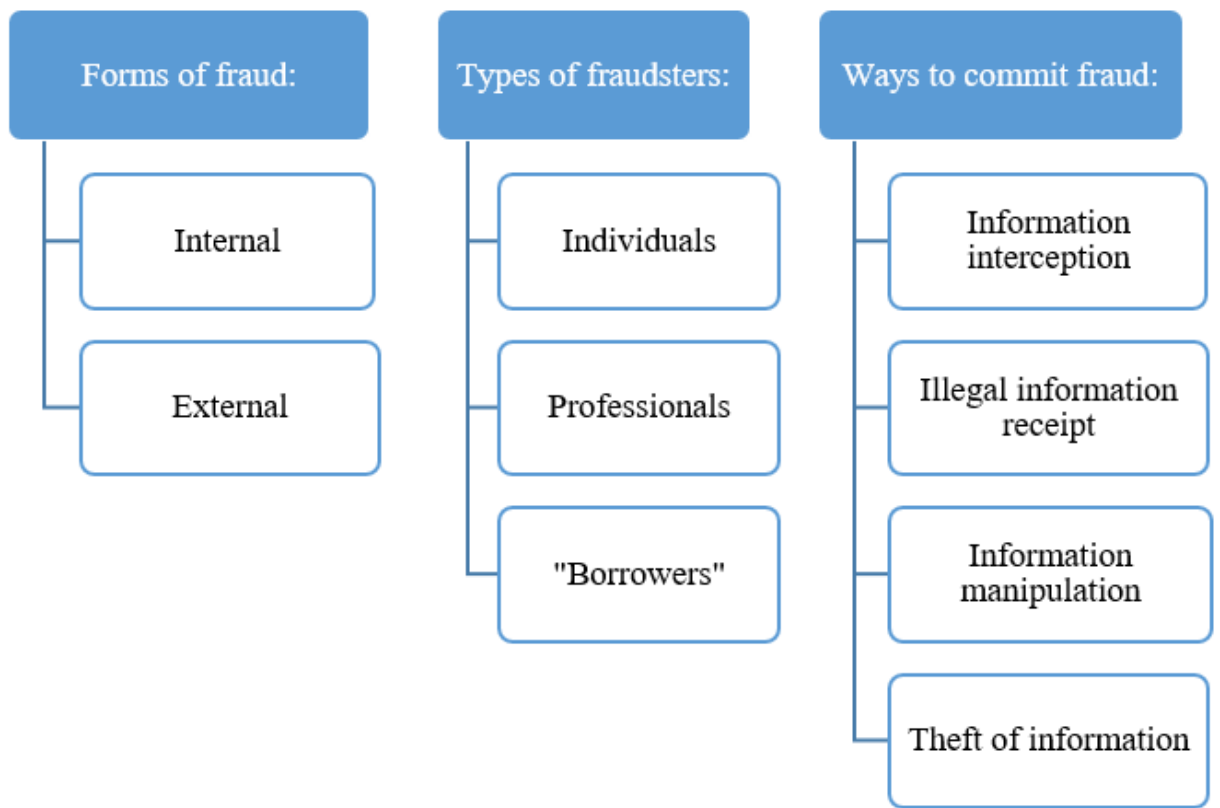

Figure 1. Fraud in the banking system.

Systematization of the main forms, types, methods and causes of bank fraud commission allows to assess the shortcomings and gaps that may affect the increasing level of bank fraud and identify possible ways to combat these types of crimes.

Factors affecting the level of fraud in the banking system can be divided into three main groups: banking system shortcomings, the shortcomings of legal and regulatory framework and the actions of bank customers. To increase the effectiveness of combatting and counteraction to banking fraud, it is advisable to implement measures aimed at overcoming each group of factors.

Table 1.

Factors increasing the level of bank fraud and possible ways to overcome it.

\begin{tabular}{|c|c|c|}
\hline & Factor & Ways to overcome \\
\hline 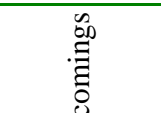 & $\begin{array}{l}\text { Low efficiency of banking activities } \\
\text { monitoring }\end{array}$ & $\begin{array}{l}\text { Establishing uniform standards for auditing and } \\
\text { verification of banking activities in accordance with } \\
\text { international standards }\end{array}$ \\
\hline $\begin{array}{l}\frac{5}{0} \\
\frac{0}{5} \\
\vdots \\
\vdots\end{array}$ & $\begin{array}{l}\text { Insufficient verification of bank } \\
\text { customers }\end{array}$ & $\begin{array}{l}\text { Creating a single customer base of financial } \\
\text { institutions, with preserving data concerning their } \\
\text { credit history }\end{array}$ \\
\hline 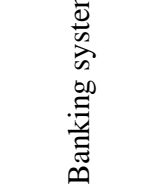 & $\begin{array}{l}\text { Opportunities for bank employees to } \\
\text { commit fraud }\end{array}$ & $\begin{array}{l}\text { 1) creation of a single database of banking } \\
\text { institutions employees; } \\
\text { 2) establishing liability for bank employees for } \\
\text { violating the standards of the banking institution } \\
\text { activities. }\end{array}$ \\
\hline $\begin{array}{l}-4 \\
0 \\
\infty \\
.0 \\
\Xi\end{array}$ & Difficulties in detecting bank fraud & $\begin{array}{l}\text { Involvement of IT specialists, financiers and } \\
\text { financial auditors in the process of detecting and } \\
\text { investigating bank fraud }\end{array}$ \\
\hline 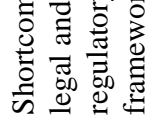 & $\begin{array}{l}\text { Lack of interaction of banking } \\
\text { institutions with law enforcement } \\
\text { agencies }\end{array}$ & $\begin{array}{l}\text { Introduction of state standards of interaction } \\
\text { between law enforcement agencies and banking } \\
\text { institutions }\end{array}$ \\
\hline ङ્ & $\begin{array}{l}\text { Disclosure of personal financial } \\
\text { information to relatives and friends }\end{array}$ & $\begin{array}{l}\text { Informative activities with the bank customers in } \\
\text { regard to the need to maintain the confidentiality of } \\
\text { personal banking data }\end{array}$ \\
\hline 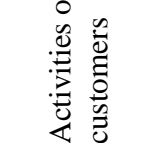 & $\begin{array}{l}\text { Providing access to banking information } \\
\text { to the third parties (fraudsters) }\end{array}$ & $\begin{array}{l}\text { Educational activities with the population on } \\
\text { possible ways of committing banking fraud and the } \\
\text { need to maintain the confidentiality of personal } \\
\text { banking data }\end{array}$ \\
\hline
\end{tabular}




\section{AMAZONDA \\ Drvestiga}

That is, improving the effectiveness of banking fraud combating can be achieved through comprehensive implementation of changes in the security system and monitoring of banking activities, amendments to regulations and optimization of banking fraud investigations, as well as educational and informational activities for the population.

According to a study carried out by Sanusia et al, (2015), bank affiliates are more vulnerable to fraud. According to the results of the study, the level of fraud can be reduced by the following actions:

1) comprehensive verification of the documents submitted, for example, crosschecking of the information provided in the

certificates of salary, clarification of the employer's information about the position and status of the employee; verification of financial declarations and verification in other relevant authorities;

2) checking the applicant's credit history and the ability to repay the bank loan;

3) involvement of professional appraisers in the bank affiliates, who will carry out property appraisal.

Positive trends in reducing the level of bank fraud in developed countries indicate the effectiveness of combating these types of crimes. Therefore, it is advisable to compare the antifraud system in the banking sector of developed countries and Ukraine.

Table 2. Anti-bank fraud system

\begin{tabular}{|c|c|c|}
\hline Country & Legal regulation & Financial monitoring \\
\hline $\begin{array}{l}\text { Great } \\
\text { Britain }\end{array}$ & $\begin{array}{l}\text { The Fraud Act. (CPS, 2020). } \\
\text { Cooperation within FIRST, the International } \\
\text { Telecommunication Union, } \\
\text { Groups of European Computer Emergency } \\
\text { Response Centers } \\
\text { (EGC group), TF-CSIRT, NATO, OSCE, } \\
\text { UN }\end{array}$ & $\begin{array}{l}\text { Is carried out by the Inland Revenue Service NCIS / ECU, } \\
\text { which is subordinated to the UK Treasury and interacts } \\
\text { with the National Criminal Intelligence Service, Customs } \\
\text { and Excise, the Anti-Fraud Office and the National } \\
\text { Investigation Service. }\end{array}$ \\
\hline France & $\begin{array}{l}\text { Digital Economy Law (Lexology, 2004). } \\
\text { Cooperation with the Federal Office for } \\
\text { Information Security of Germany (BSI). }\end{array}$ & $\begin{array}{l}\text { Administrative model of financial monitoring. } \\
\text { Activities of TRACFIN - a body, which is provided with } \\
\text { information on setting up bank accounts of individuals and } \\
\text { legal entities. }\end{array}$ \\
\hline Italy & $\begin{array}{l}\text { Italian legislation requires banks and other } \\
\text { intermediaries to keep detailed records } \\
\text { concerning residents' foreign exchange } \\
\text { transactions in order to prevent fraud and } \\
\text { money laundering attempts. (Di Vizio, } \\
\text { 2017). The legislation provides for banks and } \\
\text { other financial institutions to keep detailed } \\
\text { documentation on all foreign exchange }\end{array}$ & $\begin{array}{l}\text { The state is obliged to monitor the detection and cessation } \\
\text { of money laundering attempts. The monitoring is carried } \\
\text { out by the Ufficio Italiano Combi UIC (SAR), which } \\
\text { reports to the National Bank of Italy. } \\
\text { Identification of legal entities and individuals upon receipt } \\
\text { or payment of cash (or its equivalent), bearer securities, the } \\
\text { amount of which exceeds } 12.5 \text { thousand euros, is } \\
\text { mandatory. }\end{array}$ \\
\hline Spain & $\begin{array}{l}\text { The Law on the Participation of Financial } \\
\text { Institutions in Anti-Money Laundering and } \\
\text { Anti- Drug Trafficking (1990), The Law on } \\
\text { the Certain Measures against Money } \\
\text { Laundering (Law 10/2010, 2010) and the } \\
\text { Monetary and Financial Code (European } \\
\text { Banking Federation, 2002). }\end{array}$ & $\begin{array}{l}\text { The monitoring is carried out by TRACFIN, which is an } \\
\text { agency of the French Ministry of Finance. } \\
\text { Among the subjects of financial monitoring, it is } \\
\text { appropriate to mention auditors, accountants, tax advisors, } \\
\text { organizations selling antiques and pieces of art. Financial } \\
\text { monitoring entities are obliged to provide information to } \\
\text { the financial intelligence unit on transactions if they } \\
\text { involve the transfer of cash, checks or other documents to } \\
\text { the bearer, as well as on transactions with residents of } \\
\text { offshore jurisdictions in the amount exceeding } 30 \text { thousand } \\
\text { euros. }\end{array}$ \\
\hline USA & $\begin{array}{l}\text { Legal Act - PATRIOT Act } 2001 \text { (Uniting } \\
\text { and Strengthening America by Providing } \\
\text { Appropriate Tools Required to Intercept and } \\
\text { Obstruct Terrorism) } \\
\text { Controlling bodies: The U.S. Department of } \\
\text { the Treasury, Office of the Comptroller of } \\
\text { the Currency, The Board of Governors of the } \\
\text { Federal Reserve System), FinCEN (Financial } \\
\text { Crimes Enforcement Network). } \\
\text { In 2020, the Anti-Money Laundering Law } \\
\text { was approved. }\end{array}$ & $\begin{array}{l}\text { The financial monitoring system is based on extending } \\
\text { authorities of government bodies; strengthening and } \\
\text { improving the procedure for financial institutions to } \\
\text { implement measures to prevent fraud in the banking } \\
\text { system. }\end{array}$ \\
\hline
\end{tabular}


So, the international system of banking fraud combating is characterized by the following features:

- clear definition of the legal framework, subjects and objects of regulation;

- establishing strict liability for noncompliance with the law;

- interaction of structural subdivisions and controlling bodies within the country;

- international cooperation on the basis of international agreements and acts in regard to banking fraud combating;

- state control over financial monitoring of risk-oriented approach.

Based on the analysis of international experience, effective measures to combat banking fraud are as follows:

- investment in monitoring the implementation of the requirements of international financial institutions to combat financial crime (anti-money laundering and terrorist financing (AML CTF), bribery and corruption $(\mathrm{ABC})$;

- introduction of integrated reporting, integrated management structures, integrated systems and staff responsibilities with fraud risk management and financial crime combating compliance (KPMG, 2019);

- changes in legislation with clearly defined subjects, objects of regulation and liability for breach of the law;

- increase of the country's cybersecurity, interaction with cyber police;

- combating money laundering and financing of terrorism, corruption and other interrelated crimes;

- involvement of external experts for risk assessment and financial monitoring.

At the same time, banking fraud is not a separate problem of modern society, which can be solved independently. Fraud in the banking sector is interrelated with the following social problems:

- increasing the money laundering and terrorist financing level;

- the presence of corruption schemes in the country, both in the financial, political and legal system;

- low material standard of living of the Ukrainian population;

- $\quad$ socio-economic and political instability.
Therefore, combatting against banking fraud can not be considered separately from these social problems. Therefore, improving the effectiveness of combatting against banking fraud can have a positive impact on solving these problems, reduce money laundering level, eradicate corruption in the banking system and promote socio-economic and political stability in the country.

Fraud in the banking sector can cause huge losses in terms of the financial market, banking and financial institutions and payment systems operation. From the point of view of customers' psychology, bank fraud can lead to customer distrust, which in the future may adversely affect the integrity and stability of the economy. Such influence can destroy the banking system and cause public discontent and political turmoil. Another obstacle to combat fraud in the banking sector may be the inexperience and low level of awareness of employees in regard to fraud prevention. In this respect, it is important to train employees to combat fraud, which will positively affect the level of employees' compliance and improve the attitude to banking procedures. The interaction of relevant committees, special public and interbank associations can have a positive effect on reducing the bank fraud level, due to the creation of common models for fraud detection and exchanging current information on existing ways of committing fraud, its detection and counteraction.

Maintaining the level of customer confidence in banking institutions can be reached through informational and educational activities that can protect the bank's customers from the confidential information disclosure and from the loss of money due to fraudulent actions.

In terms of banking institutions activity, work can be done to increase the efficiency of monitoring and tracking of suspicious banking transactions. Tracking the territorial position of financial transactions by the client will help to prevent fraud. If the transaction is carried out elsewhere in the country or in the world, by increasing control of the transaction - requesting additional information or confirmation of the customer, it is possible to avoid bank fraud commitment.

Effective counteraction of fraud in the banking sector and combatting it can be reached by introducing reliable information technology equipment of the bank's security service; introduction of a unified clients' database of relevant institutions, training of employees of 


\section{AMAZONUA \\ Investiga}

credit (deposit) banking units concerning fraud prevention, organization of enhanced
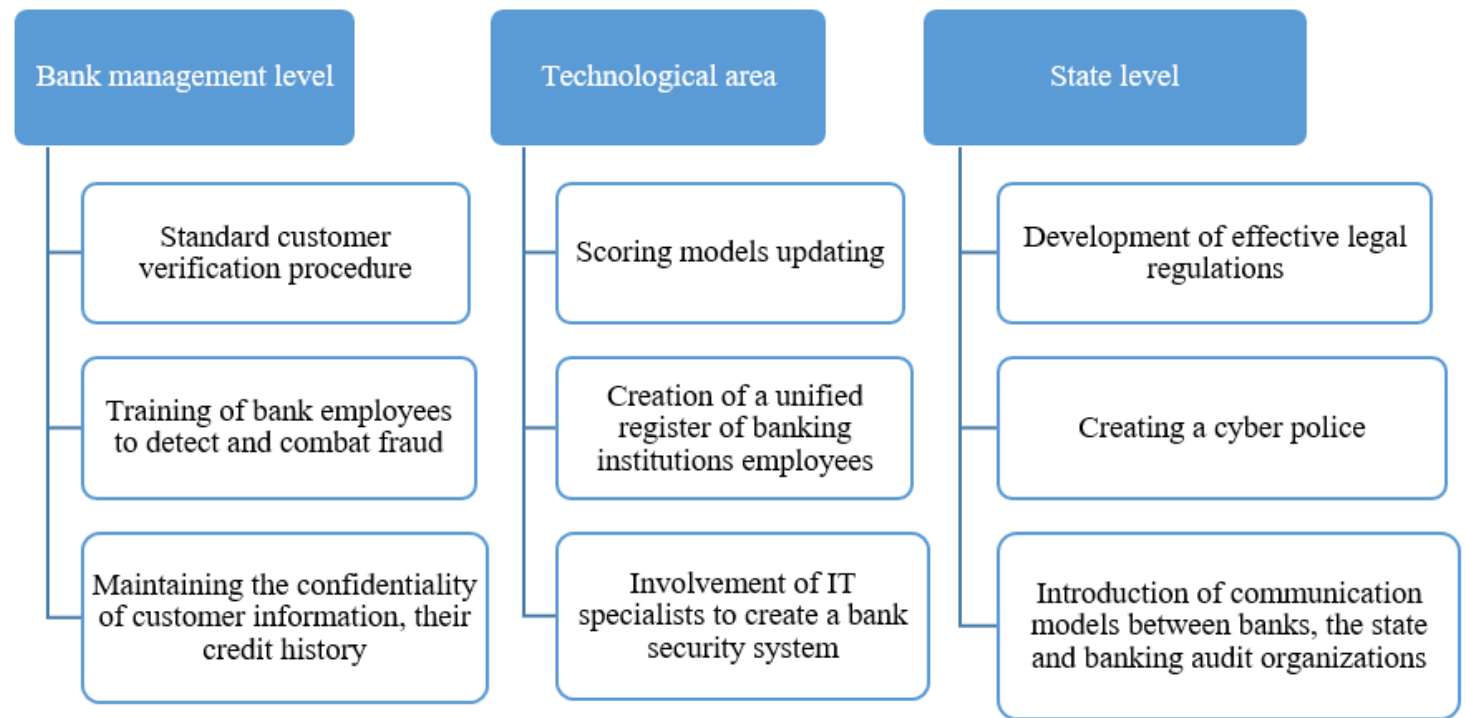

Figure 2. Anti-fraud system in the banking sector

Factors affecting the level of banking fraud also include:

1) financial stability of the banking institution, the increase of which may help reduce the level of fraud;

2) complex bank transactions, poor financial performance, low capacity of the bank to pay debts may increase the level of fraud;

3) poor internal control over the activities of managers and employees of the bank may increase the level of banking fraud;

4) failure of bank managers to comply with the standards of the institution plays the greatest role as a factor in increasing the level of fraud (Nafchi \& Dastgir, 2019).

These factors can be solved through the establishment of an independent board of directors, which will monitor compliance with the standards of the banking institution, the revival of a culture of honesty and trust among bank employees and conduct seminars and trainings for the staff.

Anti-fraud system in the banking sector should be comprehensive and systematic, including the interaction of the state, banking institutions and organizations conducting audit and control of bank activities. Coordinated actions in the following areas can be effective ways to combat fraud in the banking sector: banking institution management, legal regulatory support and technological area. cooperation between representatives of the financial sector and law enforcement agencies. models between banks, the state and banking audit organizations
Development of organization strategy and definition of control tools aimed at analyzing potential threats as a result of internal and external abuses; periodical training and education for bank employees, aimed at improving knowledge on detecting and combating fraud in the banking system; establishing an effective communication model between the banking units, the bank's security service and law enforcement agencies; reporting on the results of suspicious transactions monitoring and transferring relevant information to the security service and higher authorities; Regular assessment of the bank's operating procedures for compliance with statutory standards will be able to reduce the level of banking fraud and increase the security level of banking institutions.

The anti-fraud strategy in the banking sector should be focused not only on improving the security level, but also on creating conditions under which fraudsters will know that they will be punished for sure for the committed crime. In this respect, it may be effective to create conditions in which a fraudster will not be willing to commit a crime and will believe in a guaranteed punishment, which will turn worse than the reward for fraud, which will represent a warning factor.

It is important for the bank to be able to protect itself against fraudulent activities by strengthening the mechanism for detecting, mitigating and controlling fraud through prompt detection, investigation and information 
exchange. This can have a positive impact not only on banks security, but also ensure the resistance and stability of the financial system as a whole and maintain public confidence in financial institutions.

\section{Conclusion}

This study was aimed at identifying the main trends in the causes and consequences of bank fraud, features and methods of committing such crimes. In order to determine effective ways to combat bank fraud, international legislation and the system of financial monitoring of developed countries, which are characterized by a low level of bank fraud, were analyzed.

The increase in the banking fraud level can be influenced by: corporate crime, imperfection of banks safe operation ensuring system, rapid development of technology, information availability, financial transactions poor control, simplification of the bank customers identification system, shortcomings of legal and regulatory framework of banking institutions.

The analysis of the international bank fraud combating system revealed the features peculiar to the countries with high effectiveness in combating bank fraud: clear definition of the legal framework, subjects and objects of regulation, strict and guaranteed liability for breach of laws, interaction of structural units and controlling authorities at the domestic and international level, state control of financial monitoring of the risk-oriented approach.

It is possible to increase the effectiveness of bank fraud combating in Ukraine as a result of the implementation of the following measures: the application of countermeasures at the bank management level (creation of a standard customer verification system, training of bank employees to combat bank fraud, maintaining information confidentiality, enhancing customer identification control); at the state level (development of effective legal regulations, creation and interaction with cyber police, introduction of communication models between banks, the state and organizations conducting banking institutions audits); at the technological level (scoring models updating, creation of a unified register of banking institutions employees, involvement of IT specialists to increase the bank security system efficiency).

As a result of the study, it was concluded that bank fraud combating cannot be considered separately from combating against corruption, money laundering and terrorist financing. Reducing the level of bank fraud in the country will help increase confidence in banking institutions, economic development and financial stability of the state.

\section{Bibliographic references}

Afanasenko, S.I. (2014). Features of the mechanism of victim behavior of victims of fraud. South Ukrainian Law Journal. 3, 58-61. (In Ukrainian)

Agwu, E. (2012) Generations $\mathrm{X}$ and $\mathrm{Y}^{\text {ees }}$ adoption of internet and internet banking in Nigeria: a qualitative study. International Journal of Online Marketing, 2 (4), 68-81.

Agwu, E.M. (2013) Cyber criminals on the internet super highways: A technical investigation of different shades and colours within the Nigerian cyber space. International Journal of Online Marketing, 3(2), 56-74.

Agwu, E.M. (2014). An investigative analysis of factors influencing E-business adoption and maintenance of commercial websites in Nigeria. Basic Research Journal of Business Management and Accounts. 3 (1), 05-16. Retrieved from https://www.academia.edu/9331760/Agwu E_M_2014_An_investigative_analysis_of_f actors_influencing_E_business_adoption_an d_maintenance_of_commercial_websites_in _Nigeria_Basic_Research_Journal_of_Busin ess_Management_and_Accounts_ISSN_231 5_6899_Vol_3_1_pp_05_16_January_2014 _Available_online_http_www_basicresearch journals_org.

Association of Certified Fraud Examiners (ACFE). (2014). Report to the Nation on Occupational Fraud and Abuse. Austin, Texas: ACFE. Retrieved from https://www.acfe.com/rttn/docs/2014-reportto-nations.pdf.

Baranovsky, O.I. (2014). Philosophy of security: monograph: in 2 vols. Kiev: UBS NBU, 2: Security of financial institutions. (In Ukrainian)

Beasley, M.S. (1996). An Empirical Analysis of the Relation between the Board of Director Composition and Financial Statement Fraud. The Accounting Review, 71, 443-465.

Bhasin, M. (2007). The Bank Internal Auditor as Fraud Buster. The ICFAI Journal of Audit Practice, 4(1). Retrieved from https://management.nirmauni.ac.in/wpcontent/uploads/sites/24/2020/11/06.-BankInternal-Auditor-as-Fraud-Buster.pdf.

Bhasin, M. (2016). Frauds in the Banking Sector: Experience of a Developing Country. Asian 


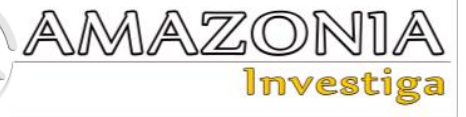

Journal of Social Sciences and Management Studies, 3, 1-9.

BNP Paribas (2018). World Payments Report. Recovered from

https://worldpaymentsreport.com/wpcontent/uploads/sites/5/2018/10/WorldPayments-Report-2018.pdf

Buchko, I.E. (2013). Scoring as a method of reducing the bank's credit risk. Bulletin of the University of Banking of the National Bank of Ukraine. 2 (17), 178-182. (In Ukrainian)

Buell, S.W. (2011). What Is Securities Fraud? Duke Law Journal, 61, 511-581.

Cherniavskyi, S.S. (2010). Financial fraud: methodological principles of investigation: a monograph. Kiev: High-TechPress. (In Ukrainian). Retrieved from https://ua1lib.org/book/3065660/89faff?id=3 $065660 \&$ secret $=89$ faff.

Chernyshov, G.M. (2014). On the question of defining financial fraud. Scientific Bulletin of Uzhhorod National University. Right, 26, 230-234. Retrieved from http://nbuv.gov.ua/UJRN/nvuzhpr_2014_26 61. (In Ukrainian)

Di Vizio, F. (2017). Money laundering from a criminal and administrative perspective. Definitions of recycling. Bank of Italy. Retrieved from https://uif.bancaditalia.it/pubblicazioni/quad erni/2017/quaderni-82017/quaderni_8_2017.pdf.

Dzhuzha, O., Golosnichenko, D., \& Chernyavsky, S. (2000). Crimes in the field of credit, financial and banking activities: criminological analysis. Law of Ukraine, 11, 36. (In Ukrainian)

European Banking Federation. (2002). Money Laundering: Legislation. National Measures. Retrieved from https://www.ebf.eu/wpcontent/uploads/2017/01/Money_Launderin g_Nov02-2004-01934-02-E.pdf

Fraud Digest. (2017). Ukrainian Interbank Association of Members of EMA Payment Systems. Recovered from https://www.ema.com.ua/news/fraud-digest28-09-2017/. (In Ukrainian)

Green, S.P. (2007). Lying, Cheating, and Stealing: A Moral Theory of White-Collar Crime. New York: Oxford University Press.

Gullkvist, B., \& Jokipii, A. (2013). Perceived importance of red flags across fraud types. Critical Perspectives on Accounting, 24, 4461.

Haugen, S. \& Selin, J.R.(1999). Identifying and controlling computer crime and employee fraud. Journal: Industrial Management \& Data Systems, 99 (8), 340-344.
Kingsley, A. (2012). Frauds In Nigerian Banks: Nature, Deep-Seated Causes. Aftermaths And Probable Remedies, 3, 279-290.

Klochko, A.M. (2015). Fraud in obtaining a bank loan. Law and society. Dnepropetrovsk. 3, 158-163. (In Ukrainian)

KPMG (2013). KPMG International. KPMG Malaysia Fraud, Bribery and Corruption Survey. Recovered from https://www.academia.edu/7301608/KPMG _Malaysia_Fraud_Bribery_and_Corruption_ Survey_2013

KPMG (2019). KPMG International. Global study on banking fraud. Multilateral threat of fraud: are banks ready to meet the challenge with dignity? (In Ukrainian). Recovered from https://assets.kpmg/content/dam/kpmg/en/pd f/2020/01/Global-Banking-Fraud-Survey.pdf

Krishevich, O.V. (2012). Methods of fraud in the banking sector: criminal law aspect. Legal Bulletin, 2 (23), 112-116. (In Ukrainian). Retrieved from http://nbuv.gov.ua/UJRN/Npnau_2012_2_25

Kriushenko, L.I. (2015). On the classification of methods of fraud in the banking sector. Bulletin of VNKarazin Kharkiv National University Law Series, 20, 261-266. (In Ukrainian). Retrieved from http://nbuv.gov.ua/UJRN/VKhIPR_2015_20 -64

Kuznetsova, N.V. (2016a). Analysis of financial risks using SAS-data processing technologies. Electrical and computer systems, 22 (98), 267-271. (In Ukrainian)

Kuznetsova, N.V. (2016b). Scoring technologies for assessing the risks of fraud in banking. Information technology and security: mat. int. scientific-practical conf. ITB-2016. (Kiev, December 1, 2016) Kiev: IPRI NAS of Ukraine, 43-47. (In Ukrainian)

Law 10/2010. The Law on the Certain Measures against Money Laundering. Official State Gazette, 28 April, 2010. Retrieved from

https://www.legislationline.org/download/id/ 8496/file/Spain_law_preventing_terrorism_f inancing_2010_am2013_en.pdf.

Lexology (2004). Digital Economy Law. Retrieved from https://www.lexology.com/commentary/ecommerce/france/franklin/franceimplements-eu-e-commerce-directive.

Lomnicka, E. (2008). Investor Protection in Securities Markets. In: Peter Cane/Joanne Conaghan (eds.), The New Oxford Companion to Law. Online edition. Oxford: Oxford University Press. 
Merchant Savvy (2020). Global Payment Fraud Statistics, Trends \& Forecasts. Recovered from

https://www.merchantsavvy.co.uk/paymentfraud-statistics/

Mordvinkin, A. (2014). Credit fraud of legal entities. $\quad$ Retrieved from http://amordvinkin.ru/ index.php/publishing/kreditovanie-malogobiznesa-prochee/115-mosh4. (In Ukrainian)

Nafchi, A.R., \& Dastgir, M. (2019). Identification and Ranking of Risk Factors Affecting the Probability of Bank Fraud (Case Study, Isfahan Province Resalat Bank). International journal of Business Management, 4 (4), 50-64. Retrieved from https://sciarena.com/storage/models/article/y tY9ZR3319jjwQinFW80jofuso2QAZdAAju ZfidgzAE9hRFa1oHlYoiZjv1A/identificatio n-and-ranking-of-risk-factors-affecting-theprobability-of-bank-fraud-case-studyisfa.pdf

Narain, B. (1992). Survival analysis and the credit granting decision. Credit Scoring and Credit Control. 1, 1-2.

Neil, F., \& Roehrkasse, A. (2013). All the Incentives Were Wrong: Opportunism and the Financial Crisis. Conference paper. American Sociological Association Annual Meeting, New York.

Nets Fraud \& Dispute services (2019). European Fraud Report - Payments Industry Challenges. Recovered from www.nets.eu/solutions/fraud-and-disputeservices.

Okpara, G.C. (2009) Bank failure and persistent distress in Nigeria: A Discriminant Analysis. Nigeria Journal of Economic and Financial Research, 2(1).

Omar, N.B., Faizal, H., \& Din, M. (2010). Fraud Diamond Risk Indicator. An Assessment of Its Importance and Usage. In International Conference on Science and Social Research, (CSSR 2010) (pp. 607-612). IEEE, 27 May 2011.

Pivovarov, V.V. (2013). On the issue of latency of corporate crime in the banking sector. Scientific Bulletin of Kherson State University. Jurisprudence, 3, 104-106. (In Ukrainian)
Popov, K.L. (2015). Uncriticality and risk as factors in increasing victimization in fraud. Bulletin of the Academy of Advocacy of Ukraine, 12, 1, 95-104. (In Ukrainian)

PwC. (2020). Worldwide research economic crimes and fraud. Retrieved from https://www.pwc.com/ua/uk/survey/2020/ec onomic-crime-survey.html

Rodchenko, S.S., \& Zhivko, Z.B. (2020). Financial fraud in the banking sector: essence, types and current state. Scientific Bulletin of Uzhhorod National University, 31, 104-108. (In Ukrainian)

Sanusia, Z.M., Ramelib, M. Nor, F., \& Isab, Y.M. (2015). Fraud Schemes in the Banking Institutions: Prevention Measures to Avoid Severe Financial Loss. Procedia Economics and Finance, 28, 107-113.

Sharma, B.R. (2004). Bank Frauds- Prevention \& Detection. Universal law Publishing Co. Pvt .Ltd. Retrieved from https://www.goodreads.com/book/show/625 8657-bank-frauds

Siddiqi, N. (2006). Credit Risk Scorecards: Developing and Implementing Intelligent Credit Scoring. John Wiley \& Sons, Hoboken.

The Crown Prosecution Service (CPS). (2020). The Fraud Act of 2006. Retrieved from https://www.cps.gov.uk/legalguidance/fraud-act-2006.

Vitvitskiy, S.S., Kurakin, O.N., Pokataev, P.S., Skriabin, O.M., \& Sanakoiev, D.B. (2021a). Formation of a new paradigm of anti-money laundering: The experience of Ukraine. Problems and Perspectives in Management, 19, 1, 354-363.

Vitvitskiy, S.S., Kurakin, O.N., Pokataev, P.S., Skriabin, O.M., \& Sanakoiev, D.B. (2021b). Peculiarities of cybercrime investigation in the banking sector of Ukraine: review and analysis. Banks and Bank Systems, 16(1), 69-80. doi: 10.21511/bbs.16(1).2021.07

Wells, J.T. (2008). Directory of prevention and detection of corporate fraud. Translation with english M.S. Sukhanova, Yu.Yu. Simirskaya, V.L. Artemova. Moscow: Maroseika. (in Russian) 